\title{
Effect of relative density and confining pressure on Poisson ratio from bender and extender elements tests
}

\author{
J. KUMAR* and B. N. MADHUSUDHAN*
}

By using the bender and extender elements tests, together with measurements of the travel times of shear (S) and primary $(\mathrm{P})$ waves, the variation of Poisson ratio $(v)$ was determined for dry sands with respect to changes in relative densities and effective confining pressures $\left(\sigma_{3}\right)$. The tests were performed for three different ranges of particle sizes. The magnitude of the Poisson ratio decreases invariably with an increase in both the relative density and the effective confining pressure. The effect of the confining pressure on the Poisson ratio was found to become relatively more significant for fine-grained sand as compared with the coarse-grained sand. For a given material, at a particular value of $\sigma_{3}$, the magnitude of the Poisson ratio decreases, almost in a linear fashion, with an increase in the value of maximum shear modulus $\left(G_{\max }\right)$. The two widely used correlations in literature, providing the relationships among $G_{\max }$, void ratio (e) and effective confining pressure $\left(\sigma_{3}\right)$, applicable for angular granular materials, were found to compare reasonably well with the present experimental data for the fineand medium-grained sands. However, for the coarsegrained sand, these correlations tend to overestimate the values of $G_{\max }$.

KEYWORDS: dynamic properties; laboratory tests; sands; shear modulus; soil dynamics
En utilisant les tests d'éléments de cisaillement («bender ») et de compression (" extender»), et en mesurant les temps de trajet des ondes secondaires (S) et primaires $(\mathrm{P})$, on a pu déterminer la variation du ratio de Poisson (v) sur des sables secs pour des changements de densité relative et de pression de confinement effective $\left(\sigma_{3}\right)$. Les tests ont été effectués sur trois gammes de taille de particule. Le ratio de Poisson décroît invariablement avec une augmentation de la densité relative et de la pression de confinement effective. On a pu constater que l'effet de la pression de confinement sur le ratio de Poisson devient relativement plus élevé pour les sables fins, par rapport aux sables grossiers. Pour un matériau donné, et pour une valeur particulière de $\sigma_{3}$, le ratio de Poisson décroît, de façon presque linéaire, pour une augmentation de la valeur du module de cisaillement maximal $\left(G_{\max }\right)$. Les résultats ont par ailleurs démontré que les deux corrélations largement utilisées dans la littérature, portant sur les relations entre $G_{\max }$, l'indice des vides (e) et la pression de confinement effective $\left(\sigma_{3}\right)$ et étant applicables aux matériaux granulaires angulaires, concordent raisonnablement avec les données expérimentales présentées pour les sables à grain fin et moyen. Pour les grains grossiers, en revanche, ces corrélations tendent à surestimer les valeurs de $\mathbf{G}_{\max }$.

\section{INTRODUCTION}

Bender/extender elements and resonant column tests are often used to determine the dynamic properties of different soils. While the bender and extender elements tests are normally used to obtain the maximum moduli of the sample, the resonant column test can be employed to determine the variation of moduli and the damping ratio of the sample with changes in the strain level. The bender elements test has been used by various researchers mainly to find the shear wave velocity of the samples (Shirley, 1978; Shirley \& Hampton, 1978; Bates, 1989; Brignoli et al., 1996; Pennington et al., 2001; Clayton et al., 2004; Lee \& Santamarina, 2005; Leong et al., 2005). However, with the advancement of the technology, this test has also been utilised to measure the velocities of both the shear (S) and primary (P) waves. The P-wave velocity is measured by using extender elements in which both the elements either shorten or extend at the same time. The magnitude of the Poisson ratio can be computed with the simultaneous measurement of the velocities of both the $\mathrm{P}$ and $\mathrm{S}$ waves.

Manuscript received 7 January 2009; revised manuscript 14 July 2009. Published online ahead of print 21 December 2009.

Discussion on this paper closes on 1 December 2010, for further details see p. ii.

* Department of Civil Engineering, Indian Institute of Science, Bangalore-560012, India
However, there are only a few studies available (Schultheiss, 1981; Bates, 1989; Nakagawa et al., 1996, 1997; Brignoli et al., 1996; Lings \& Greening, 2001) in which an attempt has been made to measure the velocities of both the shear and primary waves in the same apparatus. Further, no exclusive investigation seems to be available in which the variation of the Poisson ratio, with changes in both the relative density (RD) and effective stresses, has been examined. Bates (1989) and Nakagawa et al. (1996) have shown that for a granular material, the magnitude of the Poisson ratio decreases with an increase in the magnitude of the effective confining pressure. Similar observations have also been reported recently by Deliormanli et al. (2007) on marble samples with respect to the effect of very high confining pressures on the Poisson ratio. In the present note, an attempt has been made to study the variation of the Poisson ratio with respect to changes in the $R D$ and effective confining pressure for dry sand. Three different ranges of particle sizes of the chosen sand were chosen. A number of bender and extender elements tests were carried out by measuring the travel times of the $\mathrm{S}$ and $\mathrm{P}$ waves. Three different approaches, as given below, were used to find the travel time

(a) the first time of arrival

(b) the first peak to peak

(c) the cross-correlation method. 
The obtained values of $G_{\max }$ from the present study were also compared with the two widely used empirical correlations which are applicable for granular materials and are given by Hardin \& Richart (1963) and Hardin \& Drnevich (1972).

\section{MATERIAL PROPERTIES}

All the tests in this investigation were performed on dry sand samples. From the X-ray diffraction study it was noted that the primary mineral present in the chosen sand was quartz. Three different particle size ranges were selected for performing all the experiments: coarse-grained sand $(2.0 \mathrm{~mm}-4.75 \mathrm{~mm})$, medium-grained sand $(0.425 \mathrm{~mm}-$ $2.0 \mathrm{~mm})$ and fine-grained sand $(0.075 \mathrm{~mm}-0.425 \mathrm{~mm})$. The grain size distribution curves of the three different chosen materials are provided in Fig. 1. Scanning electron microscope (SEM) images of these three different ranges of particle size are shown in Fig. 2. It can be seen from these pictures that for the fine and medium-grained sands, the particles are generally angular, on the other hand, for the coarse-grained sand, the particles are generally sub-angular. The values of specific gravity $(G)$, minimum and maximum unit weights $\left(\gamma_{\min }\right.$ and $\left.\gamma_{\max }\right)$ and the various gradation parameters of the different grain size ranges of the sand are provided in Table 1. It is shown that the minimum and maximum dry unit weights of the sample are

(a) 13.35 and $16.58 \mathrm{kN} / \mathrm{m}^{3}$ for the fine-grained sand

(b) 13.51 and $16.83 \mathrm{kN} / \mathrm{m}^{3}$ for the medium grain size sand (c) 13.66 and $16.88 \mathrm{kN} / \mathrm{m}^{3}$ for the coarse-grained sand.

Five different RDs, as shown in Table 2, were used for performing the various tests; the RDs of the samples were varied between $40 \%$ and $80 \%$. Table 2 provides the corresponding values of dry unit weight $\left(\gamma_{\mathrm{d}}\right)$ and void ratio $(e)$ associated with the chosen values of different RDs. All the samples at different RDs are prepared with the pluviation technique (Vaid \& Negussey, 1984; Cresswell et al., 1999). In order to achieve a particular value of the $\mathrm{RD}$, a specific height of the fall of the sand needs to be used. The sand was allowed to fall in polyvinyl chloride (PVC) tubes of diameter $45 \mathrm{~mm}$ and different lengths of these tubes were used in order to achieve different heights of fall. A wire mesh, having an aperture size of $2 \mathrm{~mm}$, was placed at the top end of the tube in order to obtain a uniform spread of sand. The sand on the top of the wire mesh was allowed to fall from the nozzle of a funnel, having top diameter $75 \mathrm{~mm}$, height $60 \mathrm{~mm}$, an apex angle $60^{\circ}$ and with a nozzle size of $5 \mathrm{~mm}$. The heights of the fall in different cases corresponding to different RDs for the three chosen sands are provided in Table 2. It can be noted that with an

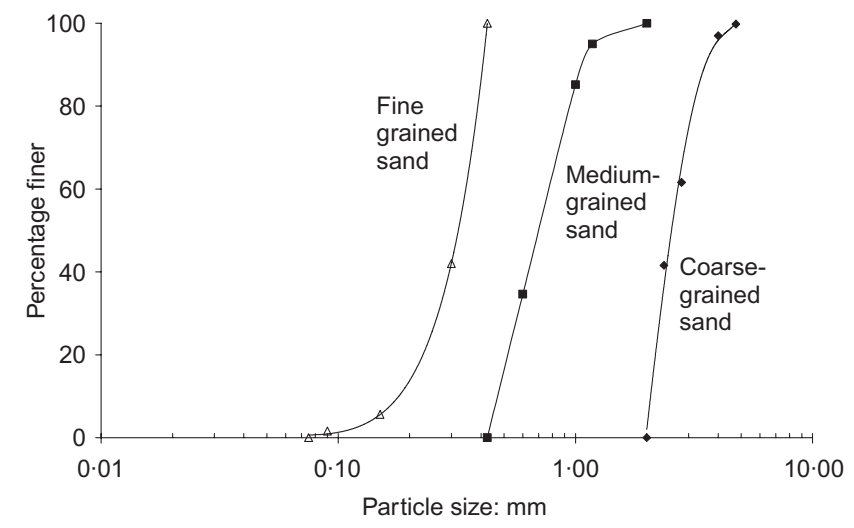

Fig. 1. The grain size distribution curves of the three chosen particle size ranges of the sand

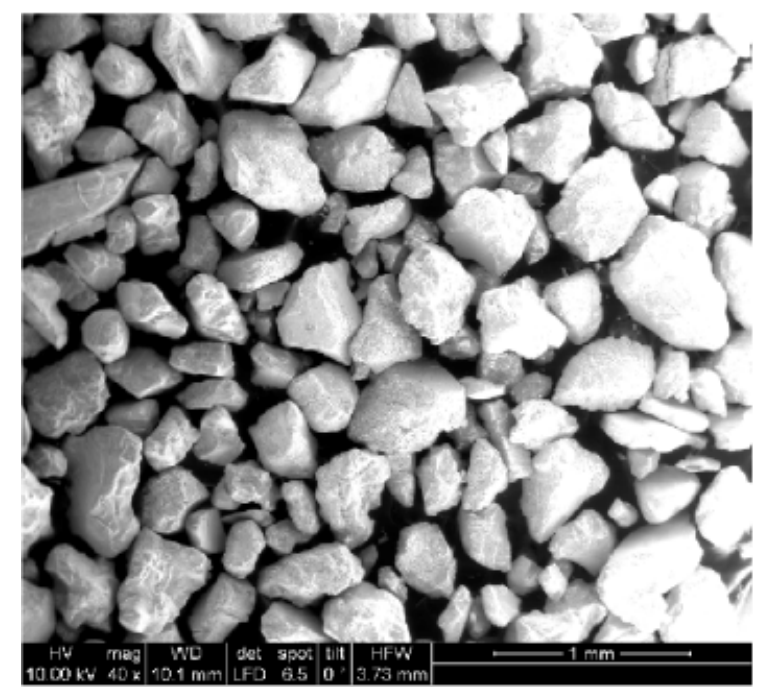

(a)

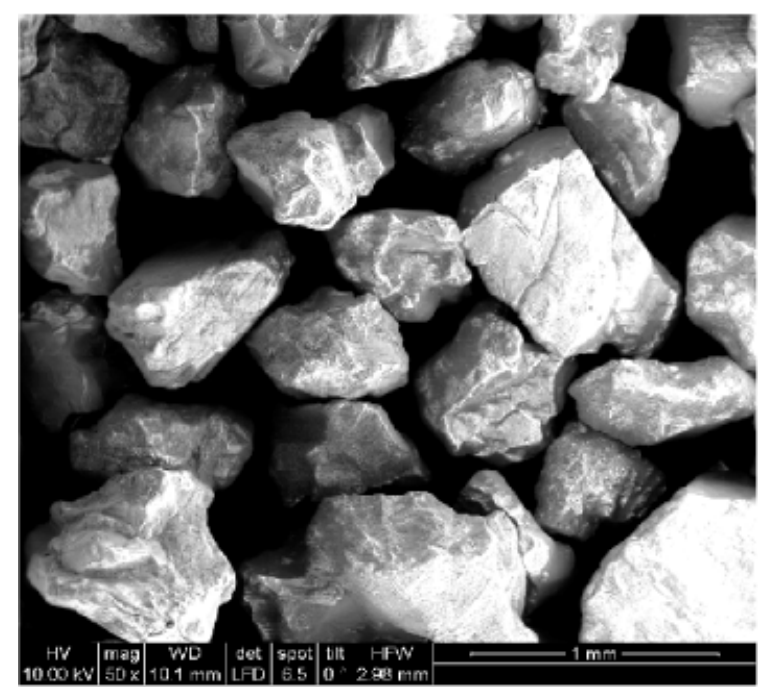

(b)

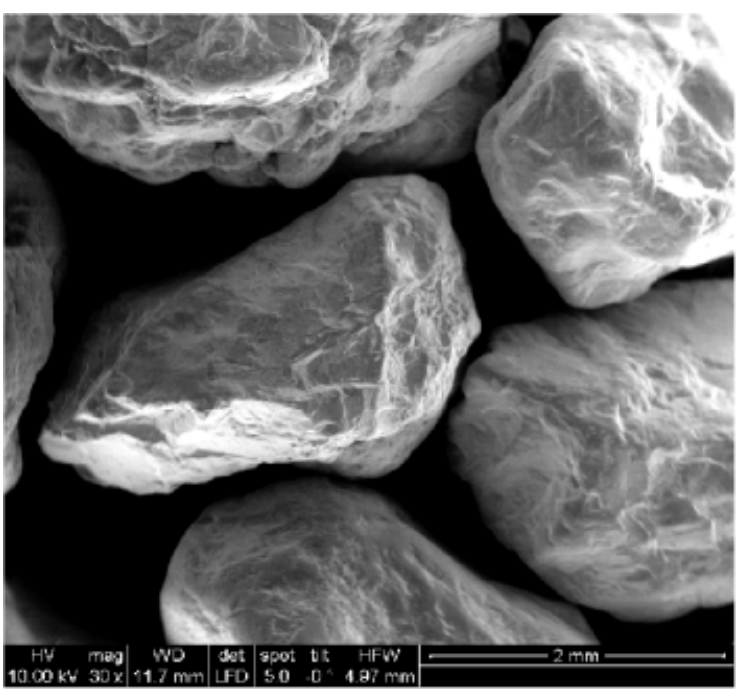

(c)

Fig. 2. Scanning electron microscope (SEM) images of the (a) fine-grained sand; (b) medium-grained sand; and (c) coarse-grained sand 
Table 1. Basic properties of the chosen sand

\begin{tabular}{|c|c|c|c|}
\hline & Coarse-grained sand & Medium-grained sand & Fine-grained sand \\
\hline Specific gravity $(G)$ & $2 \cdot 647$ & $2 \cdot 663$ & $2 \cdot 69$ \\
\hline Degree of roundness of particles & Sub-angular & Angular & Angular \\
\hline Maximum dry density $\left(\gamma_{\mathrm{dmax}}\right): \mathrm{kN} / \mathrm{m}^{3}$ & $16 \cdot 88$ & $16 \cdot 83$ & $16 \cdot 58$ \\
\hline Minimum dry density $\left(\gamma_{\mathrm{dmin}}\right): \mathrm{kN} / \mathrm{m}^{3}$ & $13 \cdot 66$ & $13 \cdot 51$ & $13 \cdot 35$ \\
\hline Maximum void ratio $\left(e_{\max }\right)$ & $0 \cdot 90$ & 0.99 & $0 \cdot 97$ \\
\hline Minimum void ratio $\left(e_{\min }\right)$ & $0 \cdot 54$ & $0 \cdot 55$ & $0 \cdot 59$ \\
\hline $\mathrm{D} 10 ; \mathrm{mm}$ & $2 \cdot 08$ & 0.47 & $0 \cdot 17$ \\
\hline D30; $\mathrm{mm}$ & $2 \cdot 26$ & $0 \cdot 57$ & $0 \cdot 25$ \\
\hline$D 60 ; \mathrm{mm}$ & $2 \cdot 76$ & $0 \cdot 80$ & $0 \cdot 34$ \\
\hline Uniformity coefficient, $C_{\mathrm{u}}$ & $1 \cdot 32$ & $1 \cdot 68$ & $2 \cdot 01$ \\
\hline Coefficient of curvature, $C_{\mathrm{c}}$ & $0 \cdot 88$ & $0 \cdot 87$ & $1 \cdot 10$ \\
\hline
\end{tabular}

Table 2. Relative density, dry unit weight, void ratio and the associated heights of fall in the pluviation technique

\begin{tabular}{|c|c|c|c|c|c|c|c|c|c|}
\hline \multirow{2}{*}{$\begin{array}{l}\text { Relative } \\
\text { density } \\
(\text { RD in \%) }\end{array}$} & \multicolumn{3}{|c|}{ Coarse-grained sand } & \multicolumn{3}{|c|}{ Medium-grained sand } & \multicolumn{3}{|c|}{ Fine-grained sand } \\
\hline & $\gamma_{\mathrm{d}}: \mathrm{kN} / \mathrm{m}^{3}$ & $\begin{array}{c}\text { Void ratio: } \\
e\end{array}$ & $\begin{array}{l}\text { Height of } \\
\text { fall: } \mathrm{mm}\end{array}$ & $\gamma_{\mathrm{d}}: \mathrm{kN} / \mathrm{m}^{3}$ & $\begin{array}{c}\text { Void ratio: } \\
e\end{array}$ & $\begin{array}{l}\text { Height of } \\
\text { fall: } \mathrm{mm}\end{array}$ & $\gamma_{\mathrm{d}}: \mathrm{kN} / \mathrm{m}^{3}$ & $\begin{array}{c}\text { Void ratio: } \\
e\end{array}$ & $\begin{array}{l}\text { Height of } \\
\text { fall: } \mathrm{mm}\end{array}$ \\
\hline 40 & $14 \cdot 79$ & $0 \cdot 755$ & $91 \cdot 86$ & $14 \cdot 67$ & $0 \cdot 781$ & $48 \cdot 24$ & $14 \cdot 45$ & $0 \cdot 826$ & $75 \cdot 15$ \\
\hline 50 & $15 \cdot 10$ & 0.719 & $142 \cdot 36$ & $14 \cdot 99$ & 0.743 & $68 \cdot 35$ & $14 \cdot 80$ & 0.784 & $91 \cdot 76$ \\
\hline 60 & $15 \cdot 42$ & $0 \cdot 683$ & $271 \cdot 68$ & $15 \cdot 32$ & $0 \cdot 704$ & $88 \cdot 47$ & $15 \cdot 12$ & 0.745 & $118 \cdot 30$ \\
\hline 70 & $15 \cdot 76$ & $0 \cdot 647$ & $304 \cdot 22$ & $15 \cdot 67$ & 0.666 & $126 \cdot 22$ & $15 \cdot 46$ & $0 \cdot 707$ & $157 \cdot 92$ \\
\hline 80 & $16 \cdot 12$ & $0 \cdot 611$ & $501 \cdot 65$ & $16 \cdot 04$ & 0.628 & $400 \cdot 42$ & $15 \cdot 81$ & 0.668 & $294 \cdot 13$ \\
\hline
\end{tabular}

increase in the height of fall, the RD of the sample increased continuously; for $80 \%$ RDs of sand the required height of fall becomes very large. The sample was composed of five different layers having equal thickness. Bender and extender elements tests were carried out by preparing a homogeneous soil sample of size $50 \mathrm{~mm}$ (diameter) $\times 100 \mathrm{~mm}$ (height). The sample was placed in silicon oil with the help of a Perspex cylinder. Air pressure was then applied using an air compressor to achieve the required magnitude of the effective consolidation all around pressure $\left(\sigma_{3}\right)$. Cell pressure was applied and controlled by a GDS air pressure control system connected to the air compressor. The cell pressure application and monitoring was done by using GDSLAB software (GDS Instruments, Hook, Hampshire, UK).

\section{TESTING PROCEDURE}

The bender/extender elements test set-up, supplied by GDS Instruments, UK, was used in this research programme. The vertical bender/extender element insets used in this study were made from piezoelectric ceramic bi-morphs; two sheets were bonded together with a metal shim between them. The combined $\mathrm{P}$ and $\mathrm{S}$ wave transducers consist of two element inserts. In the apparatus, the elements were wired in two different fashions in order to generate and receive $\mathrm{P}$ and $\mathrm{S}$ waves. The $\mathrm{S}$-wave source/P-wave receiver was at the top of the sample, whereas the P-wave source/ $\mathrm{S}$-wave receiver was placed at the bottom. An excitation voltage was applied to produce a displacement-time sinusoidal wave sent through the sample. A function generator feeds the transmitter element with an input sine waveform voltage to bend or extend it. The wave subsequently generates a displacement in the receiver, which induces the voltage signal in the receiver that is being read. The dimensions of the bender/extender elements are $10 \mathrm{~mm}$ wide,
$1.0 \mathrm{~mm}$ thick and protruding heights of $2.0 \mathrm{~mm}$. The measurement system consists of the analogue to digital conversion of receiver signal by using a high-speed data acquisition card which has 16-bit resolution and $200 \mathrm{kHz}$ sampling rate.

After preparing the sample of a given RD, and with the application of an effective confining pressure of a certain magnitude, the bender and extender elements tests were then carried out to find the travel times of $\mathrm{S}$ and $\mathrm{P}$ waves. Subsequently, the testing was terminated and a new sample with the same RD was prepared before testing the sample at the new value of the effective confining pressure. All the tests were carried out on five different RDs and three different values of $\sigma_{3}$, namely, $100 \mathrm{kPa}, 300 \mathrm{kPa}$ and $500 \mathrm{kPa}$.

\section{TRAVEL TIME DETERMINATION IN BENDER/ EXTENDER ELEMENTS TESTS}

In order to find the travel times from source to receiver, three different methods were used: $(a)$ the first time of arrival; $(b)$ the first peak to peak; and $(c)$ the cross-correlation method (Mancuso et al., 1989; Viggiani \& Atkinson, 1995). It was noted that in the case of P-wave measurements, the difference in travel times obtained from the three different methods was found to be very marginal and the average of all three times was used for analysing all the results. In the case of S-waves, however, the first arrival time was found to be generally a little smaller as compared with the other two methods; this was perhaps on account of the generation of a minor P-wave signal owing to field effects, which reached the receiver first and made the travel times slightly smaller than that obtained from the other two methods. Therefore, in the case of S-wave measurements, the average of only two times, determined from the first peak to 
peak and the cross-correlation methods, was used for the purpose of analysing all the results.

\section{RESULTS AND COMPARISONS}

\section{The variation of the Poisson ratio}

From the known velocities, $V_{\mathrm{p}}$ and $V_{\mathrm{s}}$, of the $\mathrm{P}$-wave and $\mathrm{S}$-wave, respectively, the value of the Poisson ratio $(v)$ was determined by using the following expression (Richart et al., 1970)

$$
v=\frac{\left(0 \cdot 5 V_{\mathrm{p}}^{2}-V_{\mathrm{s}}^{2}\right)}{\left(V_{\mathrm{p}}^{2}-V_{\mathrm{s}}^{2}\right)}
$$

The obtained variations of the Poisson ratio with effective confining pressure for different RDs are shown in Figs 3(a), (b) and (c); these three sub-figures are associated with the three different particle size ranges of the chosen sand. It can be seen that the magnitude of the Poisson ratio decreases continuously with an increase in the magnitude of effective

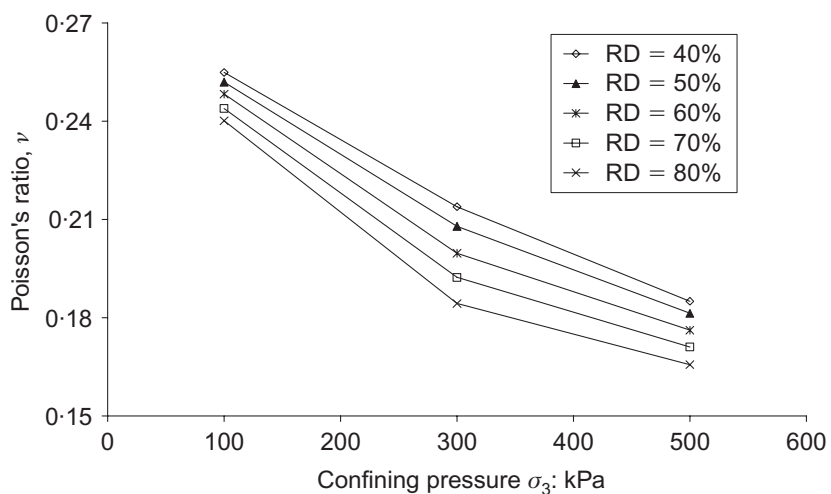

(a)

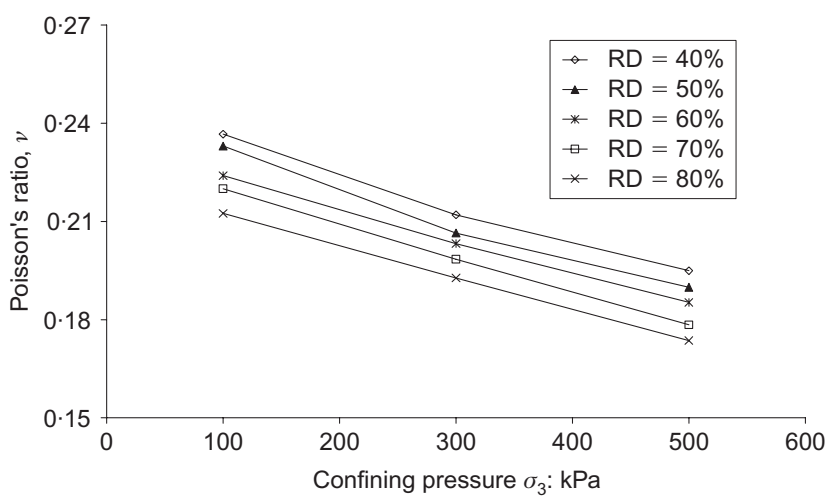

(b)

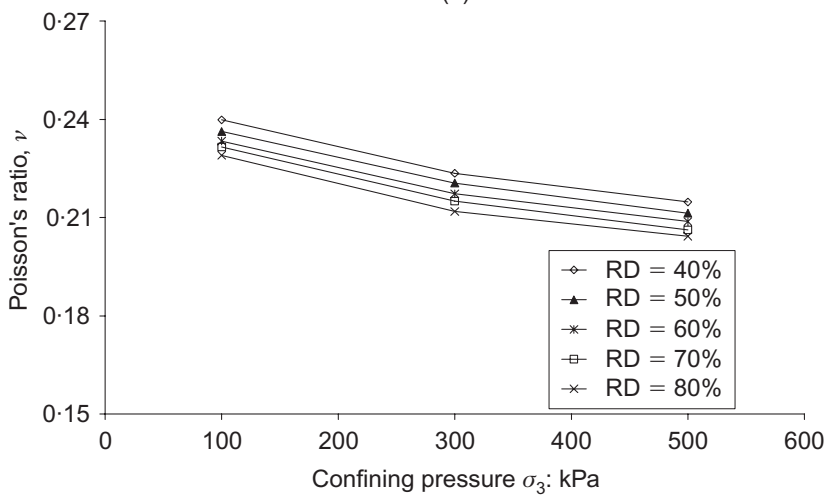

(c)

Fig. 3. The variation of the Poisson ratio with effective confining pressure at different relative densities for (a) fine-grained sand; (b) medium-grained sand; and (c) coarse-grained sand

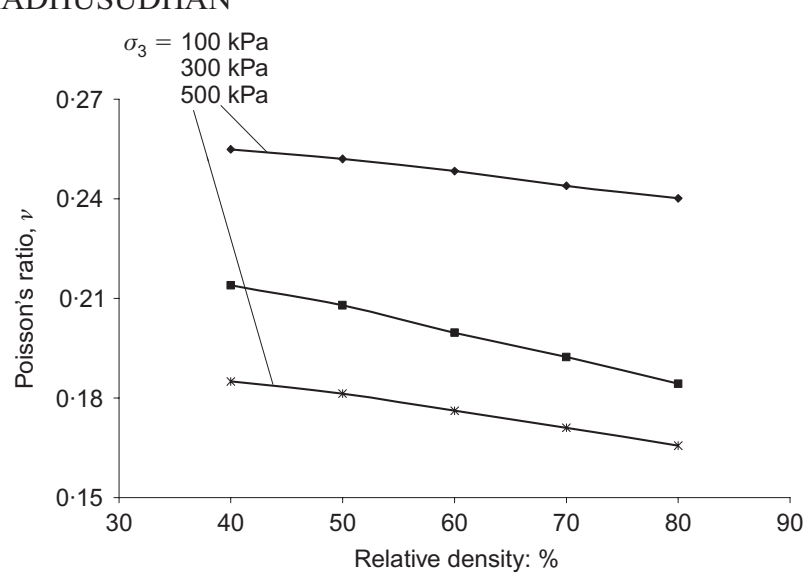

(a)

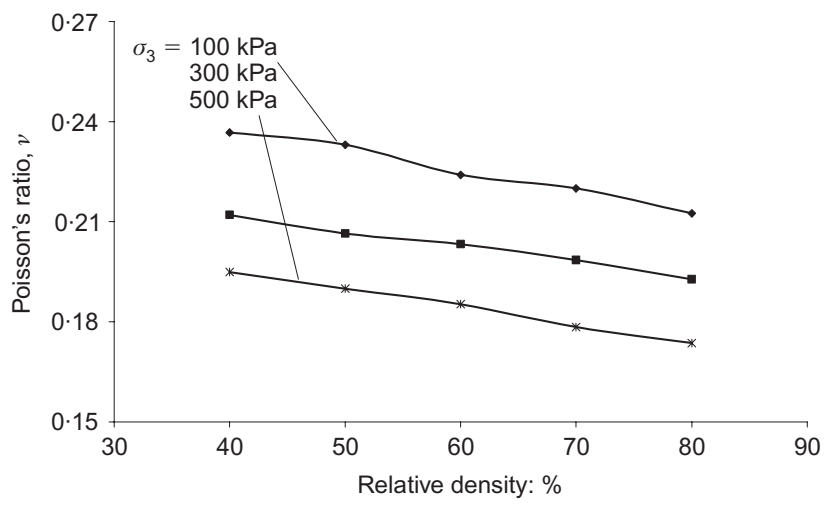

(b)

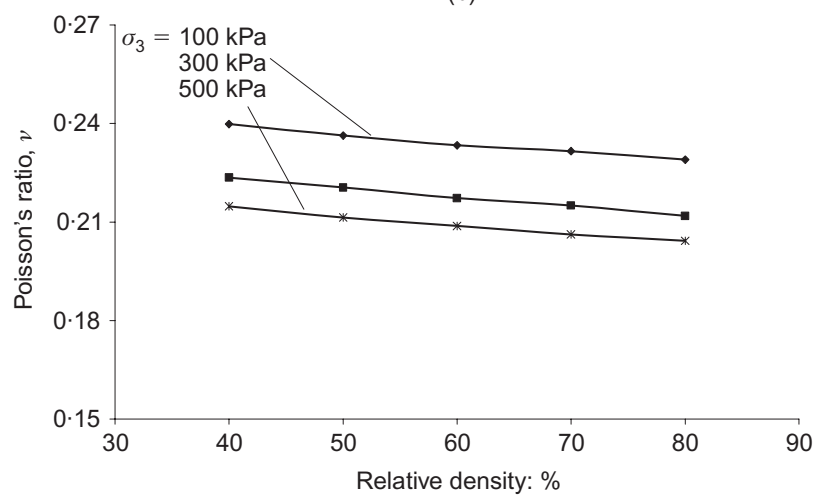

(c)

Fig. 4. The variation of the Poisson ratio with relative density at different effective confining pressures for (a) fine-grained sand; (b) medium-grained sand; and (c) coarse-grained sand

confining pressure. For greater RD, the values of the Poisson ratio become continuously lower. The values of the Poisson ratio in the different cases vary between $0 \cdot 166$ and $0 \cdot 255$ for the chosen sand. Fig. 4 provides the variation of the Poisson ratio with $\mathrm{RDs}$ for the different values of the effective confining pressures; Figs 4(a), (b) and (c) again refer to fine-, medium- and coarse-grained sand. It can be noted that the magnitudes of the Poisson ratio decrease continuously with an increase in the value of RD. It can be noted that for a given $\mathrm{RD}$, the effect of the confining pressure on the Poisson ratio becomes more substantial as the particle size of the sand becomes finer.

For a given value of $\sigma_{3}$, Fig. 5 provides the variation of $G_{\max }$ with $v$ (associated with the different RDs of the sample); Figs 5(a), (b) and (c) again refer to fine-, mediumand coarse-grained sands. In each sub-figure, three different curves are marked; these three curves are associated with $\sigma_{3}=100 \mathrm{kPa}, 300 \mathrm{kPa}$ and $500 \mathrm{kPa}$. It is noteworthy that the 


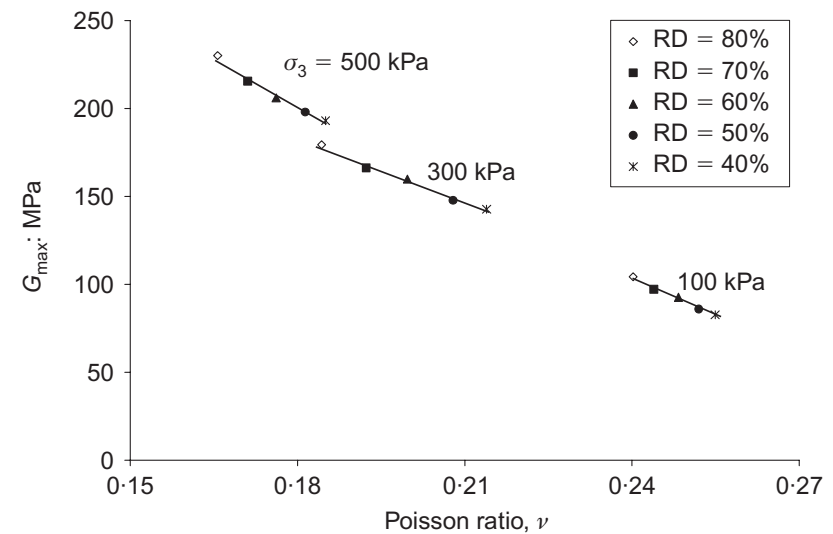

(a)

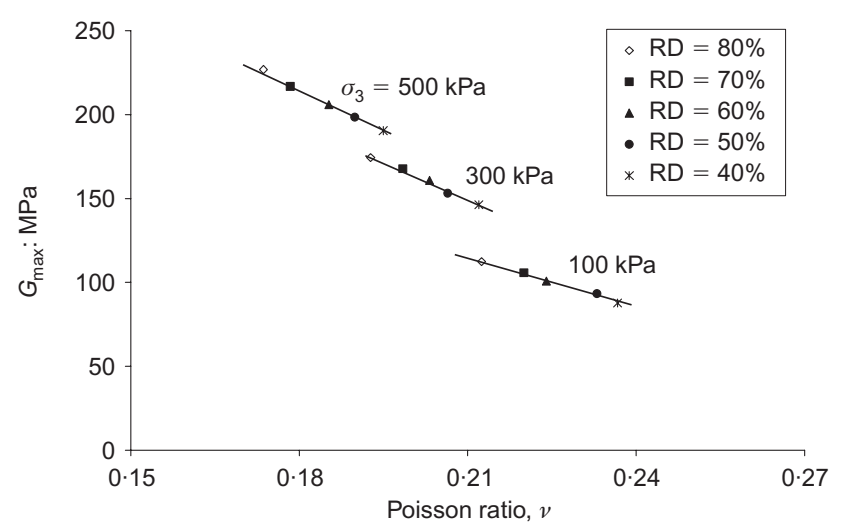

(b)

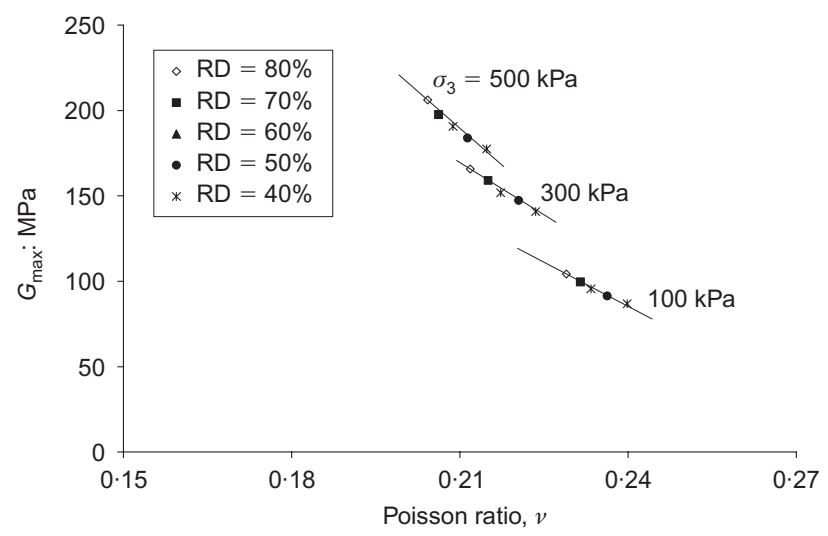

(c)

Fig. 5. The variation of $G_{\max }$ with the Poisson ratio (associated with different relative densities) at different effective confining pressures for (a) fine-grained sand; (b) medium-grained sand; and (c) coarse-grained sand relationship between $G_{\max }$ and $v$, associated with a particular size range of the sand and at a given effective confining pressure, becomes almost linear, and the magnitude of $v$ decreases continuously with an increase in the value of $G_{\max }$; this observation was found to be true for all the different cases and nine different straight lines can be observed from Fig. 5.

The present observation regarding the effect of $\sigma_{3}$ on $v$ is similar to that noted earlier by Bates (1989) and Nakagawa et al. (1996) for granular materials. A comparison was also made between the values of the Poisson ratio obtained in this study and those given by Bates (1989) for Red Wharf Bay sand and Nakagawa et al. (1997) for Montery and crystal silica sand. A comparison of these results is provided in Table 3. It can be seen that all the studies indicate a decrease in the values of the Poisson ratio with an increase in the values of $\sigma_{3}$. It is known (Lambe \& Whitman, 1979) that typically the value of the Poisson ratio of sand, associated with very small strains, varies between $0 \cdot 1$ and $0 \cdot 4$, and at failure the magnitude of the ratio may be greater than $0 \cdot 5$. Therefore, the obtained values of the Poisson ratio for sand, with different combinations of $e$ and $\sigma_{3}$, are found to lie in the expected range.

A typical variation of shear modulus with shear strain and comparison of $\mathrm{G}_{\max }$

Figure 6 provides a comparison of the variation of $G_{\max }$, with changes in void ratio, obtained from the present study with those given by the empirical correlations, applicable for different angular granular soils, developed by Hardin \& Richart (1963) and Hardin \& Drnevich (1972); the two chosen empirical correlations are provided below

Hardin and Drnevich (1972):

$$
G_{\max }=102150.95 \frac{(2.973-e)^{2}}{(1+e)} \sigma_{3}^{1 / 2}
$$

Hardin and Richart (1963):

$$
V_{\mathrm{s}}=(18 \cdot 42-6 \cdot 1986 e) \sigma_{3}^{1 / 4}
$$

In both the above correlations, $\sigma_{3}=$ effective confining pressure $\left(\mathrm{N} / \mathrm{m}^{2}\right)$ and $V_{\mathrm{s}}=$ shear wave velocity $(\mathrm{m} / \mathrm{s})$; the magnitude of $G_{\max }$ is also expressed in $\mathrm{N} / \mathrm{m}^{2}$. With the help of equation (3) the magnitude of $G_{\max }$ is calculated by using the formula $G_{\max }=V_{\mathrm{s}}^{2} \rho$; where $\rho$ is the density of the sample.

It can be noted from Fig. 6 that the correlations developed by Hardin \& Richart (1963) and Hardin \& Drnevich (1972) provide a reasonable comparison for fine- and medium-

Table 3. A comparison of obtained values of the Poisson ratio for different particle size ranges of the sand with that measured by

\begin{tabular}{|c|c|c|c|c|}
\hline $\begin{array}{l}\text { Present range of the Poisson ratio for fine-grained } \\
\text { sand }\end{array}$ & Bender/extender elements & $\begin{array}{l}0 \cdot 240-0 \cdot 255 \\
\quad(100 \mathrm{kPa})\end{array}$ & $\begin{array}{l}0 \cdot 184-0 \cdot 214 \\
\quad(300 \mathrm{kPa})\end{array}$ & $\begin{array}{l}0 \cdot 166-0 \cdot 185 \\
(500 \mathrm{kPa})\end{array}$ \\
\hline $\begin{array}{l}\text { Present range of the Poisson ratio for medium- } \\
\text { grained sand }\end{array}$ & Bender/extender elements & $\begin{array}{l}0 \cdot 212-0 \cdot 237 \\
(100 \mathrm{kPa})\end{array}$ & $\begin{array}{l}0 \cdot 193-0 \cdot 212 \\
\quad(300 \mathrm{kPa})\end{array}$ & $\begin{array}{l}0 \cdot 174-0 \cdot 195 \\
(500 \mathrm{kPa})\end{array}$ \\
\hline $\begin{array}{l}\text { Present range of the Poisson ratio for coarse- } \\
\text { grained sand }\end{array}$ & Bender/extender elements & $\begin{array}{l}0 \cdot 229-0 \cdot 240 \\
(100 \mathrm{kPa})\end{array}$ & $\begin{array}{l}0 \cdot 212-0 \cdot 224 \\
(300 \mathrm{kPa})\end{array}$ & $\begin{array}{l}0 \cdot 204-0 \cdot 215 \\
(500 \mathrm{kPa})\end{array}$ \\
\hline Poisson ratio given by Bates (1989) for Red & Bender and extender & $0 \cdot 481$ & 0.479 & 0.474 \\
\hline Wharf Bay sand & elements & $(100 \mathrm{kPa})$ & $(310 \mathrm{kPa})$ & $(510 \mathrm{kPa})$ \\
\hline Range of the Poisson ratio as determined by & Pulse transmission system & $0 \cdot 337-0 \cdot 396$ & $0 \cdot 328-0 \cdot 376$ & $0 \cdot 323-0 \cdot 366$ \\
\hline $\begin{array}{l}\text { Nakagawa et al. (1997) for different gradations } \\
\text { of sand }\end{array}$ & & $(79 \cdot 4 \mathrm{kPa})$ & $(314 \cdot 6 \mathrm{kPa})$ & $(628 \cdot 2 \mathrm{kPa})$ \\
\hline
\end{tabular}
Nakagawa et al. (1997) for Montery and crystal silica sand and Bates (1989) for Red Wharf Bay sand

The values within parentheses are the values of the corresponding effective confining pressures. 


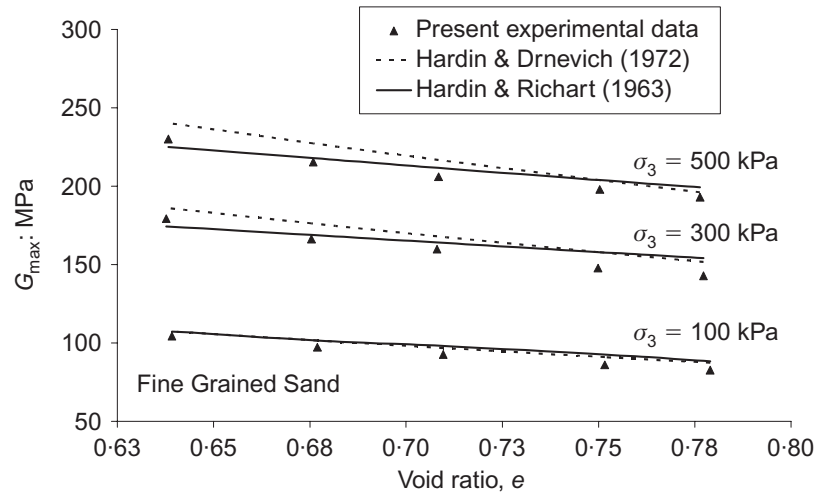

(a)

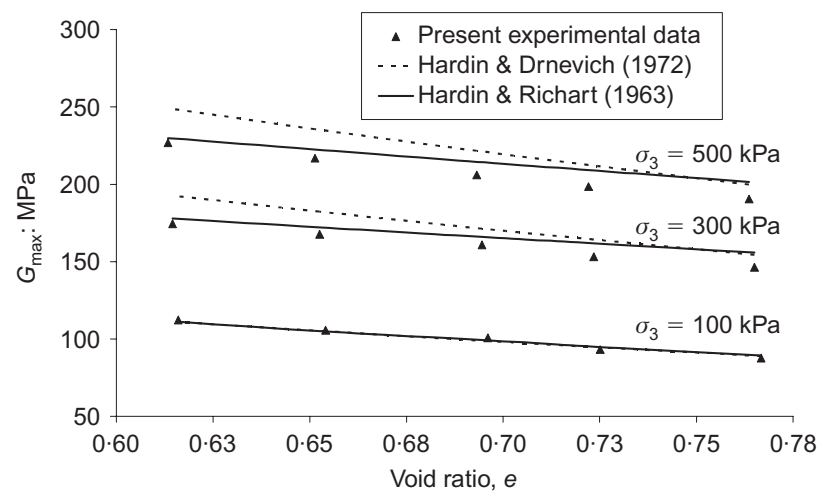

(b)

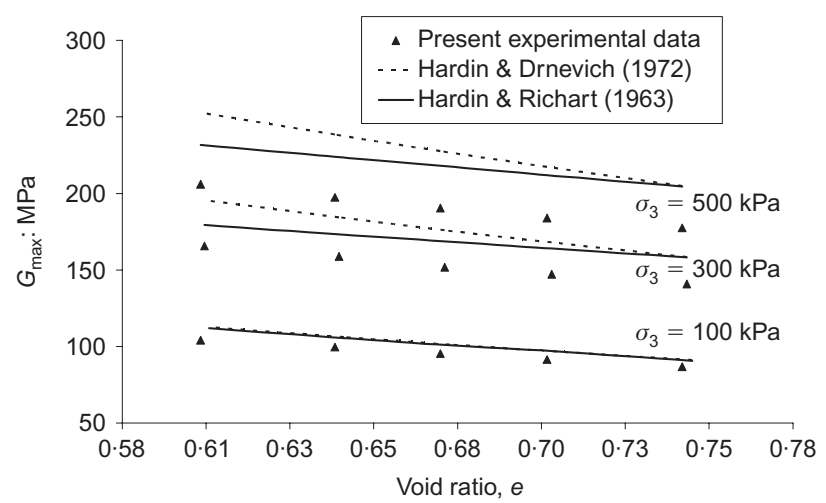

(c)

Fig. 6. A comparison of the variation of $G_{\max }$ with void ratio at different effective confining pressures for (a) fine-grained sand; (b) medium-grained sand; and (c) coarse-grained sand

grained sand. On the other hand, for the coarse-grained sand, these two correlations tend to provide much greater values of $G_{\max }$, especially at greater confining pressures.

\section{REMARKS}

(a) No attempt has been made to study the variation of the Poisson ratio with changes in the strain level. The variation of the Poisson ratio with change in strain can be obtained provided the resonant column tests are carried out at different strain levels both in the flexure and torsional modes so that the simultaneous variation of elastic modulus and shear modulus with change in strain can be measured.

(b) It should be mentioned that the void ratio values given in Figs 3 to 6 correspond to values after the application of the effective confining pressures. The initial void ratio of the sample was determined from the known dry mass of the cylindrical sample and its exact dimen- sions. After the application of the confining pressure, changes in the void ratio were computed by determining the volumetric strain from the known applied value of $\sigma_{2}$ and the computed value of the bulk modulus $\left(K_{\max }\right)$; that is, $K_{\max }=\frac{2 G_{\max }(1+v)}{3(1-2 v)}$. With the application of $\sigma_{3}$ up to $500 \mathrm{kPa}$, the changes in void ratios values were found to be quite insignificant; the changes in void ratio were found to be effective only at the level of the third decimal place, and therefore these changes have not been reported.

(c) At present, the authors are unable to provide a reason for the observed variation of the Poisson ratio with the state of soil; the state of soil is a combination of void ratio/RD and stress as defined by Atkinson (2007). More research will be needed to explain these experimental observations.

\section{CONCLUSIONS}

From a number of bender elements and extender element tests performed on dry sand, it was noted that the magnitude of the Poisson ratio invariably decrease with an increase in the magnitude of effective confining pressure and RD. The effect of the confining pressure on the Poisson ratio was found to become more substantial for the fine-grained sand as compared with the coarse-grained sand. For the given sand, at a certain effective confining pressure, the magnitude of the Poisson ratio was found to decrease almost linearly with an increase in the value of $G_{\max }$ (associated with different RDs). For fine- and medium-grained sands, a reasonable comparison was noted between the values of $G_{\max }$ measured in this study and the two widely used empirical correlations available from the literature. On the other hand, the available correlations when applied to the coarse-grained sand tend to overestimate the values of $G_{\max }$, especially at greater values of effective confining pressure.

\section{ACKNOWLEDGEMENT}

The authors would gratefully like to acknowledge the support provided by SERC Division, Department of Science and Technology, India under the project: 'Dynamic properties of cohesionless soils using resonant column and bender element tests and their effects on ground response amplification'.

\section{REFERENCES}

Atkinson, J. (2007). The mechanics of soils and foundations. London: Taylor and Francis.

Bates, C. R. (1989). Dynamic soil property measurements during triaxial testing. Géotechnique 39, No. 4, 721-726.

Brignoli, E. G. M., Gotti, M. \& Stokoe, K. H. (1996). Measurement of shear waves in laboratory specimens by means of piezoelectric transducers. Geotech. Testing J. 19, No. 4, 384-397.

Clayton, C. R. I., Theron, M. \& Best, A. I. (2004). The measurement of vertical shear-wave velocity using side-mounted bender elements in the triaxial apparatus. Géotechnique 54, No. 7, 495-498.

Cresswell, A., Barton, M. E. \& Brown, R. (1999). Determining the maximum density of sands by pluviation. Geotech. Testing $J .22$, No. 4, 324-328

Deliormanli, A. H., Burlini, L. \& Yavuz, A. B. (2007). Anisotropic dynamic elastic properties of Triassic Milas marbles from Mugla region in Turkey. Int. J. Rock Mech. Mining Sci. 44, No. 2, 279-288.

Hardin, B. O. \& Drnevich, V. P. (1972). Shear modulus and damping in soils: design equation and curves. J. Soil Mech. Found. Engng Div., ASCE 98, No. 7, 667-691.

Hardin, B. O. \& Richart, F. E. Jr. (1963). Elastic wave velocities in 
granular soils. J. Soil Mech. Found. Div., ASCE 89, No. 1, $33-65$.

Lambe, T. W. \& Whitman, R. V. (1979). Soil mechanics. New York: John Wiley.

Lee, J. S. \& Santamarina, J. C. (2005). Bender elements: performance and signal interpretation. J. Geotech. Geoenviron. Engng, ASCE 131, No. 9, 1063-1070.

Leong, E. C., Yeo, S. H. \& Rahardjo, H. (2005). Measuring shear wave velocity using bender elements. Geotech. Testing J. 28, No. $5,1-11$.

Lings, M. L. \& Greening, P. D. (2001). A novel bender/extender element for soil testing. Géotechnique 51, No. 8, 713-717.

Mancuso, C., Simonelli, A. L. \& Vinale, F. (1989). Numerical analysis of in-situ S-wave measurements. Proc. 12th Int. Conf. Soil Mech. Found. Engng, Rio de Janeiro 3, 277-280.

Nakagawa, K., Soga, K. \& Mitchell, J. K. (1996). Pulse transmission system for measuring wave propagation in soils. J. Geotech. Engng Div., ASCE 122, No. 4, 302-308.

Nakagawa, K., Soga, K. \& Mitchell, J. K. (1997). Observation of
Biot compressional wave of the second kind in granular soils. Géotechnique 47, No. 1, 133-147.

Pennington, D. S., Nash, D. F. T. \& Lings, M. L. (2001). Horizontally mounted bender elements for measuring anisotropic shear moduli in triaxial clay specimens. Geotech. Testing J. 24, No. 2, 133-144.

Richart, F. E., Hall, J. R. \& Woods, R. D. (1970). Vibrations of soils and foundations. Englewood Cliffs, NJ: Prentice Hall.

Schultheiss, P. J. (1981). Simultaneous measurements of P \& S wave velocities during conventional laboratory soil testing procedures. Mar. Geotech. 4, No. 4, 343-367.

Shirley, D. J. (1978). An improved shear wave transducer. J. Acoust. Soc. Am. 63, No. 5, 1643-1645.

Shirley, D. J. \& Hampton, L. D. (1978). Shear-wave measurements in laboratory sediments. J. Acoust. Soc. Am. 63, No. 2, 607-613.

Vaid, Y. P. \& Negussey, D. (1984). Relative density of pluviated sand samples. Soils Found. 24, No. 2, 101-105.

Viggiani, G. \& Atkinson, J. H. (1995). Interpretation of bender element tests. Géotechnique 45, No. 1, 149-154. 